\title{
Minimally invasive image-guided therapy for inoperable hepatocellular carcinoma: What is the evidence today?
}

\author{
Beatrijs A. Seinstra • Otto M. van Delden • \\ Karel J. van Erpecum • Richard van Hillegersberg • \\ Willem P. Th. M. Mali • Maurice A. A. J. van den Bosch
}

Received: 24 February 2010 /Revised: 23 May 2010 /Accepted: 28 June 2010 /Published online: 1 June 2010

(C) The Author(s) 2010. This article is published with open access at Springerlink.com

\begin{abstract}
Hepatocellular carcinoma (HCC) is a primary malignant tumor of the liver that accounts for an important health problem worldwide. Only $10-15 \%$ of HCC patients are suitable candidates for hepatic resection and liver transplantation due to the advanced stage of the disease at time of diagnosis and shortage of donors. Therefore, several minimally invasive image-guided therapies for locoregional treatment have been developed. Tumor ablative techniques are either based on thermal tumor destruction, as in radiofrequency ablation, cryoablation, microwave ablation, laser ablation and high-intensity focused ultrasound, or chemical tumor destruction, as in percutaneous ethanol injection. Image-guided catheter-based techniques rely on intra-arterial delivery of embolic, chemoembolic or radioembolic agents. These minimally invasive image-guided therapies have revolutionized the management of inoperable HCC. This review provides a description of all minimally invasive image-guided therapies currently available, an up-to-
\end{abstract}

B. A. Seinstra - W. P. T. M. Mali • M. A. A. J. van den Bosch ( $₫)$ Department of Radiology, University Medical Center Utrecht, Room E.01.132, Heidelberglaan 100,

3584 CX Utrecht, The Netherlands

e-mail: m.a.vandenbosch@umcutrecht.nl

K. J. van Erpecum

Department of Gastroenterology,

University Medical Center Utrecht,

Utrecht, The Netherlands

R. van Hillegersberg

Department of Surgery, University Medical Center Utrecht,

Utrecht, The Netherlands

O. M. van Delden

Department of Radiology, Academic Medical Center Amsterdam,

Amsterdam, The Netherlands date overview of the scientific evidence for their clinical use, and thoughts for future directions.

Keywords Hepatocellular carcinoma - Liver cancer .

Ablation techniques · Intra-arterial infusion · Embolization

\section{Introduction}

Hepatocellular carcinoma (HCC) is a primary malignant tumor of the liver that accounts for an important health problem worldwide. Primary liver cancer is the sixth most common cancer worldwide with an incidence of 626,000 patients a year, and the third most common cause of cancerrelated death [1]. There is a striking geographic variation in the incidence of HCC throughout the world [2]. The vast majority of HCC cases occur in developing countries, but incidence is on the rise in North America and Europe [3, 4].

$\mathrm{HCC}$ is a heterogeneous disease in terms of etiology and clinical behavior. It usually develops in the setting of chronic liver disease. Worldwide, the major risk factors for $\mathrm{HCC}$ are infection with the hepatitis B (HBV) and hepatitis C (HCV) viruses. In developing countries, $\mathrm{HCC}$ is mostly related to chronic HBV carrier state [5, 6]. Preventive vaccination against $\mathrm{HBV}$ infection has proven to effectively reduce the prevalence of HBV infection [7] and incidence of HCC [8]. In developed countries, HCC arises in cirrhotic livers related to hepatitis $\mathrm{C}$ virus infection or excessive alcohol intake [9-12].

Accurate staging of the disease helps to determine prognosis as well as potential therapy with the greatest survival benefit. Because conventional staging systems, like the TNM staging system, have shown important limitations for classifying patients, several new systems have recently been proposed [13]. Although there is no universally accepted HCC staging system, many have adopted the 
Barcelona Clinic Liver Cancer (BCLC) staging classification, which links the stage of the disease to a specific treatment strategy [14] (Fig. 1).

The development of effective therapeutic options for HCC is a major challenge and requires a multidisciplinary approach. Only $10-15 \%$ of HCC patients are suitable candidates for hepatic resection and liver transplantation due to the advanced stage of the disease at time of diagnosis and shortage of donors [16]. Surgical resection is restricted to patients with solitary asymptomatic $\mathrm{HCC}$ and preserved liver function who have no clinically significant portal hypertension or increased bilirubin [17-19]. Unfortunately, no systemic chemotherapy has proven to be effective in HCC patients [20], except from the oral multi-kinase inhibitor Sorafenib in advanced stage patients with Child-Pugh liver function class A [21]. In order to provide therapeutic options for patients with inoperable HCC, several minimally invasive image-guided therapies for locoregional treatment have been developed. HCC has a tendency to remain confined to the liver until the disease has advanced, making these treatments particularly attractive.

Minimally invasive image-guided therapies can be divided into the group of the tumor ablative techniques or the group of image-guided catheter-based techniques.
Tumor ablative techniques are either based on thermal tumor destruction, as in radiofrequency ablation (RFA), cryoablation, microwave ablation, laser ablation and highintensity focused ultrasound (HIFU), or chemical tumor destruction, as in percutaneous ethanol injection (PEI). These techniques are mostly used for early stage disease. Image-guided catheter-based techniques rely on intraarterial delivery of embolic, chemoembolic, or radioembolic agents [22]. These techniques enable treatment of large lesions or whole liver treatment, and are as such used for intermediate stage HCC (Figure 1).

Minimally invasive image-guided ablation techniques and intra-arterial interventions may prolong survival, spare more functioning liver tissue in comparison to surgical resection (which can be very important in cirrhotic patients), allow retreatment if necessary, and may be an effective bridge to transplantation [23-27].

During the last 2 decades, minimally invasive imageguided therapies have revolutionized the management of inoperable HCC. This review provides an overview of the different interventional techniques that are currently available in clinical practice, the scientific evidence for their clinical use, and thoughts for future directions.

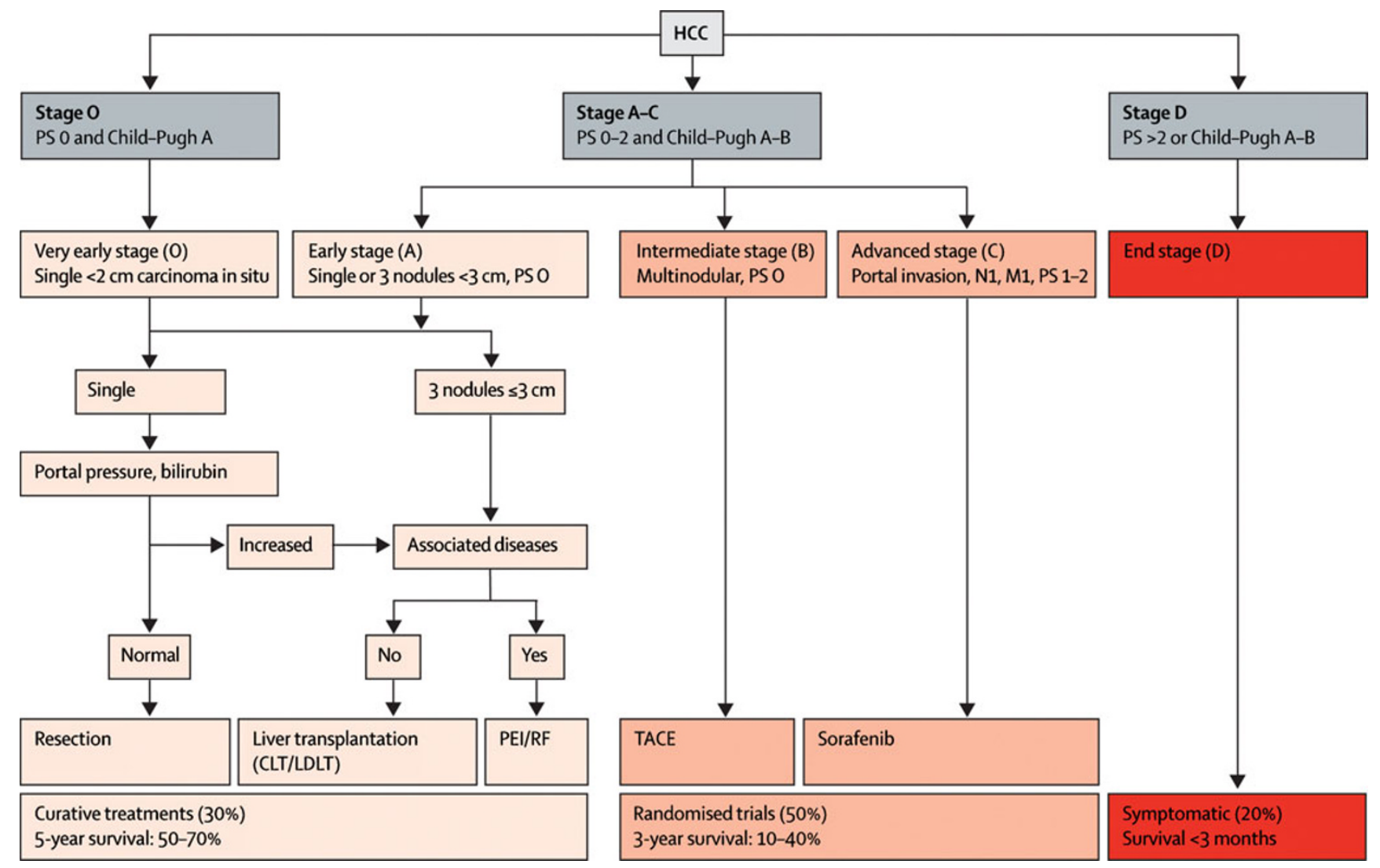

Fig. 1 Barcelona Clinic Liver Cancer staging and treatment approach. $\mathrm{PS}=$ performance status. $\mathrm{N} 1=$ lymph node involvement. $\mathrm{M} 1=$ metastatic spread. $C L T=$ cadaveric liver transplantation. $\mathrm{LDLT}=$ live-donor liver transplantation. $\mathrm{PEI}=$ percutaneous ethanol injection. $\mathrm{RF}=$ radiofrequency. $\mathrm{TACE}=$ transarterial chemoembolization. Adapted with permission from [15] 


\section{The value of image guidance}

Accurate imaging is of great importance during minimally invasive locoregional therapies to efficiently guide and monitor the treatment. It enables proper placement of instruments, like the probe in case of ablation or the catheter in case of intra-arterial therapy, and accurate monitoring of the progression of the necrotic zone during ablation. Fluoroscopy, ultrasound (US), computed tomography $(\mathrm{CT})$, and magnetic resonance imaging (MRI) can all be employed. In current clinical practice, placement of the catheter in intra-arterial procedures is usually performed under fluoroscopic guidance, while ablation may be guided by ultrasound, CT or MRI.

Ultrasound guidance allows probe insertion from every angle, offers real time visualization and correction for motion artifacts when targeting the tumor, and is low cost. However, the gas created during ablation (or ice in the case of cryoablation) hampers penetration of the ultrasound beams in tissue, causing acoustic shadowing and obscuring image details like the delineation between tumor borders and ablation zone.

$\mathrm{CT}$ is also frequently used to guide minimally invasive ablation therapy, and is a reliable modality to confirm treatment results. In comparison to US, it provides increased lesion discrimination, a more reliable depiction of ablated/non-ablated interfaces, and a better correlation to pathologic size [28]. However, due to its hypervascularity, small HCCs can only be clearly visualized in the arterial phase for a short period of time. Another disadvantage of $\mathrm{CT}$ is the exposure of the patient and physician to ionizing radiation. Combining US imaging for probe placement and $\mathrm{CT}$ for ablation monitoring reduces this exposure. At the moment, hybrid systems are being developed, enabling combination of imaging techniques, like ultrasound and CT imaging, thereby improving the registration accuracy during treatment [29].

The interest in MRI-guided ablation is growing, as it produces a high-quality image allowing high-sensitivity tumor detection and accurate identification of the target region with multiplanar imaging. MRI also enables real-time monitoring of the temperature evolution during treatment [30-35]. However, MRI is an expensive technique, and MRI-guided ablation is still limited in clinical practice.

\section{Tumor ablation techniques}

Percutaneous ethanol injection

Prior to the clinical introduction of thermal tumor ablation techniques, percutaneous ethanol injection (PEI) was widely used for treatment of HCC. PEI was introduced into clinical practice in the 1980 s, being the first percutaneous treatment for HCC $[36,37]$. With this technique, $95 \%$ ethanol is injected directly into the tumor, using ultrasound or CT guidance. Ethanol induces local tumor necrosis as a result of cellular dehydration, protein denaturation, and chemical occlusion of tumor vessels[38].

Best results are seen with small, uninodular tumors of $3 \mathrm{~cm}$ or less, with response rates approaching $100 \%$ [39, 40]. Repeated procedures are often needed to obtain complete tumor ablation, especially for larger lesions. Three-year survival rates of $79 \%, 63 \%$, and $12 \%$ have been reported for patients with single HCC of $5 \mathrm{~cm}$ or smaller with Child-Pugh cirrhosis class A, B or C, respectively [41]. Complications of PEI consist of local pain, fever, and abscess formation [42].

While PEI proved to be a valuable treatment for preferably small HCC lesions, several randomized controlled trials indicate that its effectiveness in small HCCs is outrun by RFA [39, 43-46]. These studies indicate that RFA is superior to PEI with respect to overall survival, cancer-free survival rates, local recurrence, and tumor response[47]. Nowadays, PEI is used when thermal ablation such as RFA cannot be performed safely, for example, in cases in which the tumor is located in close proximity to bowel loops, bile ducts, or other sites in which thermal ablative techniques are risky.

\section{Radiofrequency ablation}

Currently, the most widely used ablation technique for percutaneous treatment of focal hepatic malignancies is radiofrequency ablation (RFA), which has been shown to be safe and effective for the treatment of early stage HCC [48-50]. During RFA, a small electrode is placed within the tumor, and a high-frequency alternating electric current (approximately $400 \mathrm{MHz}$ ) is generated, causing ionic agitation within the tissue. The movement of ions within the tissue then creates frictional heat as they try to follow this alternating current, resulting in high tissue temperatures inducing coagulative necrosis and cell death. RFA can be employed via laparotomy (potentially in combination with surgical resection), laparoscopy or percutaneously. Image guidance is used for proper electrode placement and to monitor the progression of the necrotic zone during ablation. Most frequently ultrasound is used for image guidance (Figs. 2, 3), but there are reports of groups who use CT, MRI, or fluoroscopic imaging.

It is difficult to draw definite conclusions about the efficacy of RFA, as most published data consist of nonrandomized uncontrolled cohort studies. The differences in outcome measures, techniques, approaches and RFA electrode designs in these studies add complexity to interpretation of these data. 

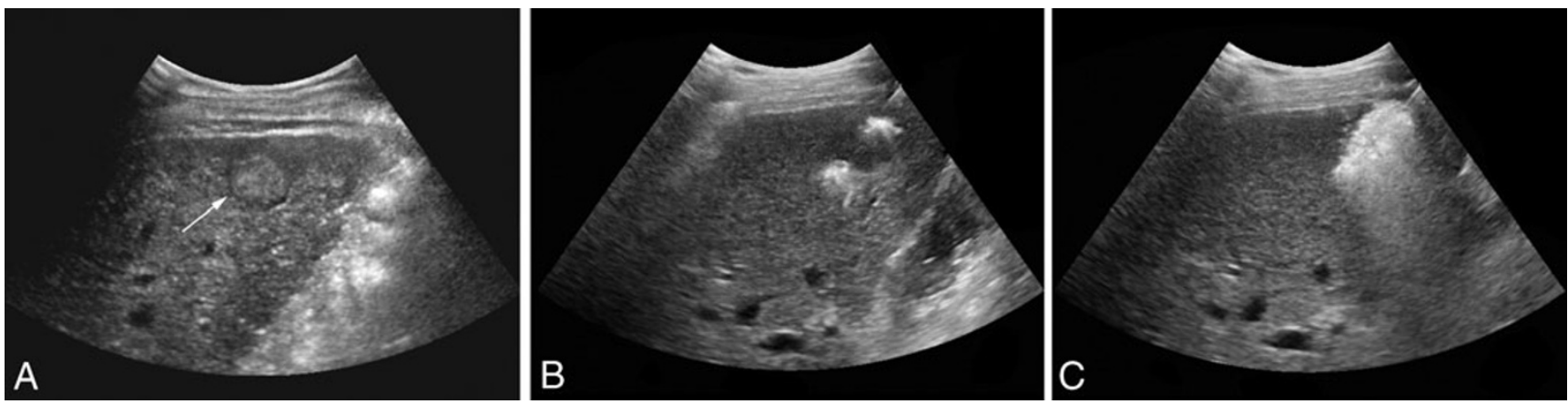

Fig. 2 Ultrasound guided RFA. a: HCC lesion in a non-surgical patient pre-treatment (pointed out by arrow). b: Just after start treatment, electrode placed centrally in the tumor. c: Gas formation during ablation causes acoustic shadowing

Predictors of complete ablation (or complete response) are small size $(\leq 3 \mathrm{~cm})$ tumors and well-differentiated and non-infiltrative HCCs [51]. Several studies have reported complete ablation rates of $80-100 \%$ in $\mathrm{HCCs} \leq 3 \mathrm{~cm}, 50$ $80 \%$ in HCCs $3-5 \mathrm{~cm}$, and $25 \%$ in HCCs $>5 \mathrm{~cm}[39,43-45$, $51,52]$.

The survival of patients after treatment is another important indicator of treatment success. Several recent prospective cohort studies showed long-term survival results similar to those observed after surgical resection, i.e., 5-year survival rates $33-63 \%$ (Table 1 ).

RFA is most effective against small tumors; technological limitations hinder ablation of tumors with a larger diameter. Developments in technology, like more powerful generators or bipolar multiprobe arrays, and technical maneuvers, like the application of selective vascular occlusion to reduce the 'heat sink' cooling effect of flowing blood, have allowed treatment of larger tumors [62-67]. Some authors have reported that RFA may be a safe and effective bridge to liver transplantation over a prolonged waiting period [23].

Percutaneous image-guided RFA of HCC is associated with a very low mortality and acceptable morbidity. Three separate multicenter studies have reported mortality rates ranging from $0.1 \%$ to $0.5 \%$, major complication rates ranging from $2.2 \%$ to $3.1 \%$ and minor complication rate ranging from $5 \%$ to $8.9 \%$ [68].

One important issue with RFA is the problem of needletrack seeding, which was reported in one study at a rate of $12.5 \%$ [69], although more recent studies show less alarming rates, ranging from $0.9 \%$ to $4 \%$ [70-72]. Needle biopsy before treatment, poor differentiation degree of the tumor, subcapsular lesions, patients treated in multiple sessions, and lesions requiring more than one electrode placement were identified as risk factors. Viable tumor cells adherent to the needle applicators were found in $12.5 \%$ of patients after ablation without track ablation [73]. To prevent tumor seeding as well as to create hemostasis, ablation along the access track is recommended. Despite the risk of needletrack seeding, RFA is considered a curative treatment for small HCC lesions, and there is ongoing debate whether RFA could potentially be considered a first option for operable patients with very early stage HCC (BCLC stage $0)[74,75]$. In a prospective randomized controlled trial (RCT) comparing percutaneous RFA to surgical resection in 180 patients with solitary HCCs $<5 \mathrm{~cm}$ in diameter, no differences in overall survival rates and cumulative recurrence-free survival rates were observed [76].

In the BCLC staging classification, patients with early stage asymptomatic $\mathrm{HCC}$ with a single nodule $<5 \mathrm{~cm}$ or
Fig. 3 Contrast-enhanced CT pre- and post-RFA. Same patient as in Fig. 2. a: Hypervascular lesion (biopsy proven $\mathrm{HCC}$ ) in right liver lobe (pointed out by arrow) before treatment. b: Ablated lesion directly post ablation, with reactive hyperemia around the RFA lesion
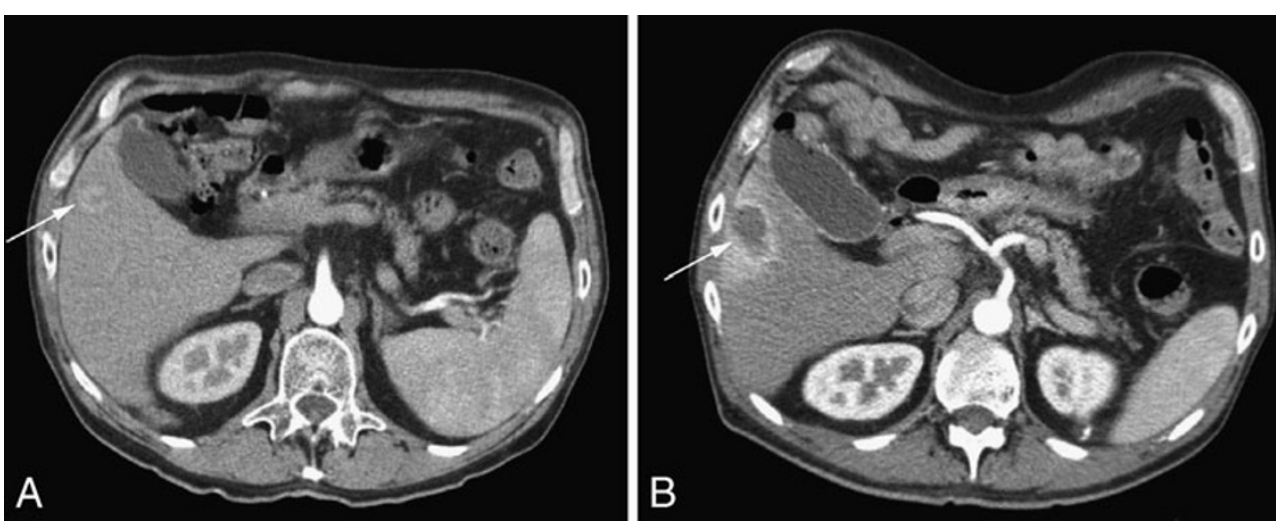
Fig. 4 Angiogram during TACE-DEB procedure. a: Hypervascular HCC caudal right lobe (segment 6) prior to treatment (arrow). NB: Patient has multifocal lesions and was previously treated with Y90 radioembolization; workup involved coiling of the gastroduodenal artery. $\mathbf{b}$ : Precision TACE with DEB shows embolization of the tumor microvasculature
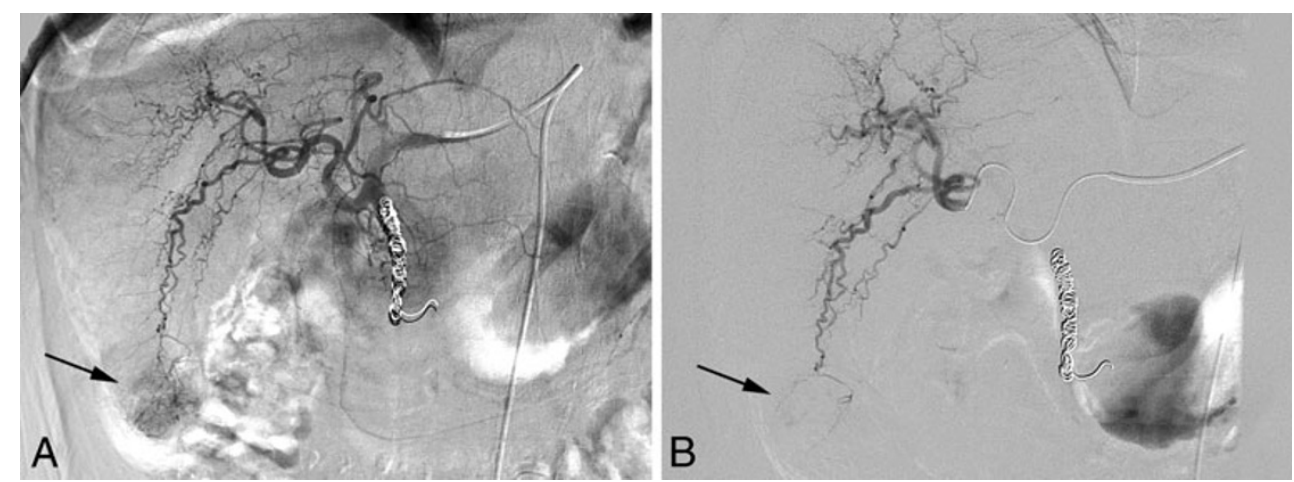

smaller or up to three nodules $<3 \mathrm{~cm}$ and Child-Pugh class $\mathrm{A}$ or $\mathrm{B}$ cirrhosis are referred to RFA.

\section{Cryoablation}

Cryoablation is a technique in which a liquid nitrogencooled cryoprobe is placed into the tumor and an ice ball is created in the target tissue. The freezing of tissue with temperatures between $-20^{\circ} \mathrm{C}$ and $-60^{\circ} \mathrm{C}$ followed by rapid thawing results in cell membrane disruption and induces cell death [77]. Cryoablation can be carried out in an open procedure, by laparoscopy, and percutaneously. Ultrasound guidance assures proper placement of the cryoprobe and enables monitoring of the ablation area. An advantage of this technique is that it can be applied for larger tumors up to $8 \mathrm{~cm}$, whereas in most tumor ablative techniques only small tumors can be successfully treated [78]. In most published studies, cryotherapy was conducted in unresectable HCC either alone or in combination with other treatment modalities, e.g., as a complement to resection to achieve total tumor eradication in otherwise unresectable patients, and long-term survival rates of $20-40 \%$ have been described $[79,80]$. However, this technique has fallen out of favor for the treatment of HCC, primarily because of the complication rate described as high as $40.7 \%$ [81] and the risk of 'cryoshock,' a life-threatening condition resulting in multiorgan failure, severe coagulopathy and disseminated intravascular coagulation following cryoablation, which has been described at a rate of $1 \%$ [82]. There are currently no randomized trials that support the use of hepatic cryoablation for HCC treatment.

\section{Microwave ablation}

Microwave ablation (MWA) induces thermal tumor destruction by induction of an alternating electric field emitted by a bipolar antenna, which is placed centrally in the tumor. Several groups have successfully proven the safety and efficacy of MWA treatment, mostly in small HCCs [83, 84]. Dong et al. reported satisfactory long-term results in larger HCCs. They treated 234 patients with a mean tumor size of $4.1 \pm 1.9 \mathrm{~cm}$ (range 1.2-8.0 cm) and reported a 5-year cumulative survival rate of $57 \%$ [85]. Liang et al. treated 288 HCC patients with a mean tumor size of $3.75 \mathrm{~cm} \pm 1.58$ (range 1.2-8.0 cm) and reported a 5-year cumulative survival rate of $51 \%$. Child-Pugh classification, tumor size, and

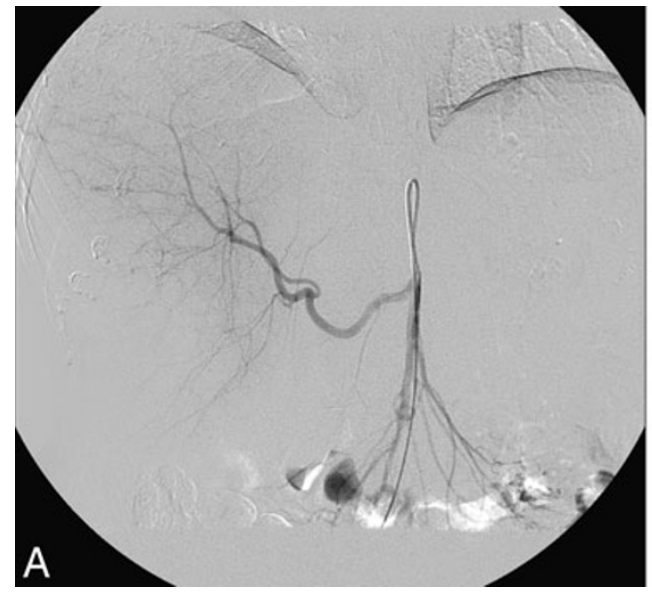

Fig. 5 Angiogram during Yttrium-90 radioembolization. a: Replaced right hepatic artery (normal variant branch from superior mesenteric artery) vascularizing a large unifocal HCC lesion in the right liver

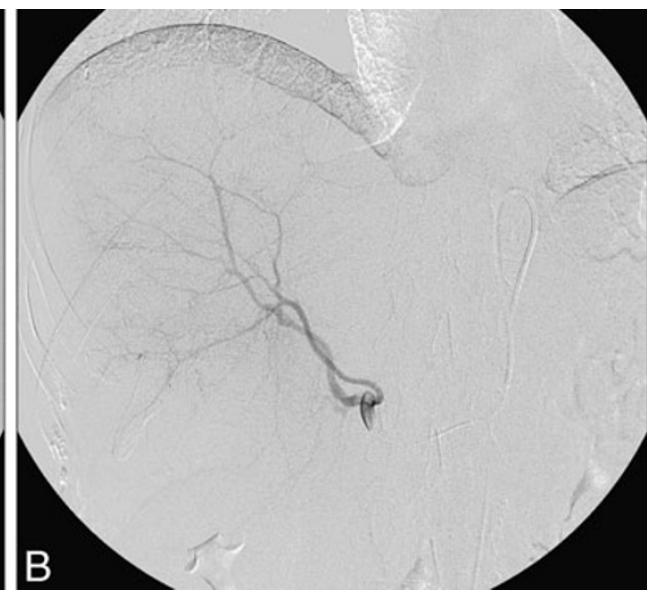

lobe. b: Selective injection of ${ }^{90} \mathrm{Y}$ microspheres through a microcatheter into the right hepatic artery 
Fig. 6 Pre- and post-Yttrium-90 radioembolization. a: Fusion image of liver MRI and 99mTcMAA scintigram showing large HCC lesion in right liver lobe. b: Contrast-enhanced MRI 3 months post-treatment shows necrotic zone centrally in $\mathrm{HCC}$
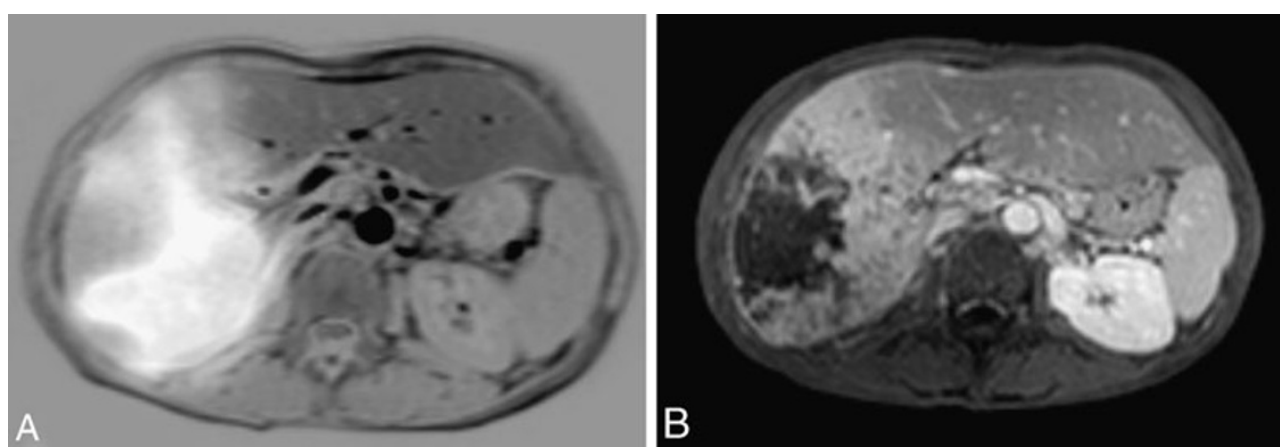

number of tumors were identified as significant independent prognostic factors. They concluded that there is a significantly higher probability of long-term survival after MWA treatment for patients with a single tumor of $4.0 \mathrm{~cm}$ or less and Child-Pugh class A cirrhosis [86]. Reported complications of MWA are similar to those reported for RFA and are typically mild, including pain, fever, liver enzyme elevation, ascites, pleural effusion, and diaphragm injury.

MWA has been compared to other ablative techniques in several studies. Seki et al. retrospectively compared MWA to PEI for small HCCs $(\leq 2 \mathrm{~cm})$. They concluded that MWA may be superior to PEI for the local control of moderately or poorly differentiated small HCCs [87]. Ohmoto et al. compared MWA to RFA for small HCCs. They suggested that RFA is more useful for the treatment of small HCCs $(\leq 2 \mathrm{~cm})$ compared to MWA, since RFA resulted in a larger area of necrosis, needed fewer treatment sessions, and showed a lower recurrence rate and higher survival rate (4-year survival 70\% versus 39\%) [88-90]. However, Lu et al. performed a retrospective comparative study and concluded that MWA and RFA were both effective methods in treating $\mathrm{HCC}$ [mean tumor diameter respectively $2.5 \mathrm{~cm}$ \pm 1.2 (range $0.9-7.2 \mathrm{~cm}$ ) and $2.6 \mathrm{~cm} \pm 1.2$ (range 1.0 $6.1 \mathrm{~cm})]$. Local tumor control, complications related to treatment, and long-term survival (4-year survival $37 \%$ for MWA versus $24 \%$ for RFA, $\mathrm{P}=0.12$ ) were equivalent for the two modalities [91]. It needs to be noted that the level of evidence of these studies is limited since they describe only a retrospective comparison of the two procedures. The only randomized study comparing MWA and RFA showed that both techniques had equivalent therapeutic effects, complication rates, and rates of residual foci of untreated disease. However, RFA offers the advantage of tumor ablation being achieved in fewer sessions (2.4 versus 1.1) [92].

In conclusion, experience with MWA of HCC is limited and still in its early stage. Preliminary work has shown that microwave ablation might be a viable alternative to other ablation techniques. Further prospective randomized studies evaluating local control, symptom palliation, and survival in a larger number of patients are necessary.
Table 1 Long-term survival data from follow-up studies of HCC patients treated with RFA

\begin{tabular}{|c|c|c|c|c|}
\hline Study & Patients (n) & $\begin{array}{l}\text { Type of } \\
\text { RFA }\end{array}$ & $\begin{array}{l}\text { Tumor size } \\
(\mathrm{cm})\end{array}$ & $\begin{array}{l}\text { 5-year overall } \\
\text { survival (\%) }\end{array}$ \\
\hline Buscarini et al. (2001)[53] & 88 & perc & $\leq 3.5$ & 33 \\
\hline Lencioni et al. (2005)[54] & 187 & perc & Mean, 2.8 & 48 \\
\hline \multirow[t]{2}{*}{ Tateishi et al. (2005)[55] } & 319 (naive) & perc & Mean, 2.6 & 54 (naive) \\
\hline & 345 (pretreated) & & & 38 (pretreated) \\
\hline \multirow[t]{4}{*}{ Raut et al. (2005)[56] } & 194 & 140 perc & Median & 55 \\
\hline & & 54 open & Total 3.3 & \\
\hline & & & Perc 3.0 & \\
\hline & & & Open 4.0 & \\
\hline \multirow[t]{5}{*}{ Machi et al. (2005)[57] } & 84 & 49 perc & Mean & 40 \\
\hline & & 20 lap & Total 3.2 & \\
\hline & & 15 open & Perc 3.2 & \\
\hline & & & Lap 3.0 & \\
\hline & & & Open 3.1 & \\
\hline Cabassa et al. (2006)[58] & 59 & perc & Mean, 3.1 & 43 \\
\hline Choi et al. (2006)[59] & 570 & perc & Mean, 2.59 & 58 \\
\hline Yan et al. (2007)[60] & 266 & perc & Mean, 3.9 & 43 \\
\hline Ueno et al. (2009)[61] & 155 & $\begin{array}{l}110 \text { perc, } 45 \\
\text { lap/open }\end{array}$ & Mean, 2.0 & 63 \\
\hline
\end{tabular}




\section{Laser ablation}

In laser ablation, also frequently called laser-induced thermotherapy (LITT), a percutaneously placed optical fiber delivers laser beams into the target tumor [93]. The energy from the photons absorbed in the tissue converts into heat, inducing coagulative necrosis. The most commonly used device for laser ablation is the Nd-YAG laser (neodymium-yttrium-aluminum-garnet laser). Most frequently, near-infrared wavelength optical radiation is used, since this accomplishes the best tissue penetration [94]. The positioning of the fibers is guided by ultrasound, CT, or MRI. A single-probe insertion can only create a small volume of ablation, so often multiple optical fibers have to be placed for treatment of larger lesions $(>5 \mathrm{~cm})$, which may be technically cumbersome and result in long treatment times. Selection criteria for LITT are broadly similar to those of other ablative techniques. Ideal lesions are less than $3 \mathrm{~cm}$ in diameter and located deep within the liver parenchyma [95].

LITT has been proven safe and feasible for the treatment of HCCs in multiple cohort studies[96-102]. Pacella et al. performed three studies in which they reported 3- and 5 -year survival rates ranging from $52 \%$ to $68 \%$ and $15 \%$ to $34 \%$, respectively $[96,98,99]$. They included patients with a single nodule $\leq 4 \mathrm{~cm}$ or three nodules $\leq 3 \mathrm{~cm}$ each. Tumor size, tumor location, and the achievement of complete response were important factors that affected survival after treatment. They stated that the ideal candidates for LITT are those with normal bilirubin levels and a small tumor size ( $\leq 2 \mathrm{~cm}$ ) [97-99]. According to Arienti et al., who performed a multicenter study with 353 patients to investigate complications, LITT is a safe treatment with a major complication rate of $1.5 \%(0.8 \%$ deaths $)$ and a minor complication rate of $6.2 \%$. They also stated that complete response was achieved in $60 \%$, regardless of tumor size, and in $81 \%$ in lesions $\leq 3 \mathrm{~cm}$ HCCs [102]. Tumor seeding after treatment has not been reported. LITT has also been proven safe and effective for the treatment of cirrhotic patients awaiting liver transplantation[103]. There is one randomized trial in which LITT is compared to RFA for treatment of early stage $\mathrm{HCC}$ (nodule $\leq 4 \mathrm{~cm}$ or three nodules $\leq 3 \mathrm{~cm}$ each). They found LITT and RFA to be equally effective; however, in the case of RFA fewer treatment sessions were needed to achieve complete response [104]. More randomized controlled trials should be carried out to compare LITT to other ablative techniques and to investigate the role of LITT in combination therapy.

High-intensity focused ultrasound

In high-intensity focused ultrasound (HIFU), an extracorporeal transducer produces high-energy ultrasound (US) beams that propagate harmlessly through the intact skin and are brought into a tight focus $(1-3 \mathrm{~mm})$ within the tumor. The rapid deposition of acoustic energy leads to an instantaneous temperature increase of $>55^{\circ} \mathrm{C}$ within the tissue, inducing coagulation necrosis [105]. HIFU offers the first completely non-invasive approach to $\mathrm{HCC}$ and is therefore a promising technology. In current practice, both conventional ultrasound and MRI are used to guide and monitor HIFU treatment. MRI offers one important advantage over US guidance, as it enables accurate monitoring of the temperature during treatment [30].

There are only a few clinical reports on the application of HIFU for HCC treatment. The majority of work is published by two groups [106, 107], who both use realtime US-guidance during treatment. Wu et al. report that HIFU treatment is effective, safe, and feasible in patients with large HCCs [106]. They treated 55 patients with a mean tumor diameter of $8.14 \mathrm{~cm} \pm 3.37$ (range $4-14 \mathrm{~cm}$ ) . Overall survival rates at 6,12 , and 18 months were respectively $86.1 \%, 61.5 \%$, and $35.3 \%$. The survival rates were higher in patients with less advanced disease according to the TNM classification. It has to be noted however that pre-procedural TACE was carried out in half of the patients and that rib resection was performed in 14 patients, taking away the non-invasive character of the procedure. In another study by Zhu et al., ribs were removed in all patients to create a better acoustic pathway. Sixteen HCC patients were treated with US-guided HIFU with a mean tumor diameter of $7.0 \mathrm{~cm} \pm 2.1$ (range 5$10 \mathrm{~cm}$ ). The 3 - and 5-year survival rates were $69.3 \%$ and $55.6 \%$, respectively [107]. As the results of these studies indicate, there are some difficulties that need to be overcome before HIFU can be used in everyday clinical practice for non-invasive treatment of HCC. The presence of the rib cage presents a problem, since the high attenuation of the ribs results in a loss of power at the focus, and reflection of the beams may induce injury to the overlying soft tissues and the skin, which may also happen when US encounters an air-filled bowel loop. However, technical solutions are underway. Civale et al. reported that this problem can be avoided by the use of a segmented transducer [108]. Liu et al. proposed to reduce the rib-overheating problem by using an independent array-element activation scheme, which switches off the transducer elements obstructed by the ribs based on feedback anatomical medical imaging [109]. Another challenge in HIFU for HCC treatment is the difficulty in targeting and monitoring since the liver is subject to respiratory movements. The main limitation to clinical use of HIFU is the fact that ablation of large volumes of the liver is still very time consuming. Next-generation phasedarray transducers and advanced MRI methods are being developed to overcome these difficulties. 


\section{Intra-arterial interventions}

Transcatheter arterial chemoembolization

Transcatheter arterial chemoembolization (TACE) is a technique that exploits the dual blood supply to the liver. HCC derives its blood supply almost entirely from the hepatic artery, while normal liver parenchyma derives $>75 \%$ of its blood supply from the portal vein [110]. This anatomical fact provides the basis for the development of arterial therapies for the treatment of $\mathrm{HCC}$, with the potential to selectively induce tumor necrosis while surrounding liver parenchyma is spared.

In TACE, a catheter is advanced into the branches of the hepatic artery directly supplying the tumor, and a highly concentrated dose of chemotherapy is delivered intraarterially in close proximity to the tumor so that systemic toxicity is minimized. The most commonly used single chemotherapeutic agent is doxorubicin. The combination of cisplatin, doxorubicin, and mitomycin $\mathrm{C}$ is the most common combination drug regimen. However, to date there is no evidence of the superiority of any chemotherapeutic agent alone or of monotherapy versus combination therapy in TACE $[111,112]$. The chemotherapeutic agent is usually mixed with an embolic agent such as lipiodol, an oily contrast medium used as a carrier for the chemotherapeutic agent and known to be selectively retained inside the tumor, thereby prolonging contact time between the drugs and the tumor cells $[113,114]$. The administration of the lipiodolized chemotherapeutic agent is followed by injection of an occluding agent. The purpose of the embolization is to reduce arterial inflow, resulting in ischemic tumor necrosis, and to diminish washout of the chemotherapeutic agent thereby prolonging contact time between cancer cells and the chemotherapeutic agent [115]. Multiple TACE protocols are used throughout the world, and the optimal method is yet to be established.

Assessing the efficacy of TACE is difficult due to its lack of standardization, and outcomes of different centers are not easily compared. As in other ablative techniques, the best measure of success is patient survival. Two RCTs [116, 117] and a systematic review [118] showed that TACE improves survival when compared to conservative treatment, provided there is a restrictive selection of candidates (Table 2). Ideal candidates for TACE are patients with multinodular asymptomatic tumors without vascular invasion or extrahepatic spread and well-preserved liver function (Child-Pugh class A).

TACE is typically well tolerated. The major side effect of TACE is the so-called postembolization syndrome, consisting of transient abdominal pain, ileus, and fever, probably due to damage of hepatocytes. It effects $40 \%-85 \%$ of patients and is usually self-limited within $48 \mathrm{~h}$ [123]. A serious complication of TACE is acute liver failure. The potential risk for this condition, which increases with larger tumors, underlying liver dysfunction and presence of portal vein thrombosis, limits the use of TACE. Other more serious treatment-related complications (hepatic abcess, ischemic cholecystitis, biliary strictures) appear in less than $10 \%$ of treatment sessions [124]. The side effects of the chemotherapeutic agents in TACE are mild and have a low rate, compared with those caused by systemic chemotherapy, and can be managed conservatively. They include nausea, vomiting, bone marrow depression, alopecia, and renal dysfunction [125, 126].

To conclude, TACE is currently the treatment of choice for multinodular, intermediate stage HCC (Fig. 1, BCLC stage B) and to be preferred over best supportive care.

Transcatheter arterial (bland) embolization

Transcatheter arterial embolization (TAE or bland embolization) consists of embolizing the artery feeding the tumor, without the use of a chemotherapeutic agent. The exact benefit of administering chemotherapy during the embolization procedure is uncertain, since HCC is known to be chemoresistant. However, hypoxia is known to be a potent stimulator of angiogenesis, and since angiogenesis is vital for tumor growth, hypoxia induced by embolization might inadvertently promote tumor growth [127]. Adding a chemotherapeutic agent may counteract this effect. No comparative clinical study to date has proven evidence of survival favoring TACE over TAE [112]. However, in recent years, TACE has replaced TAE as the most widely used and studied treatment modality for intermediate stage HCC [128].

\section{TACE-DEB}

Although conventional TACE has been shown to improve survival, the magnitude of this benefit is relatively small, so the search for more effective drug delivery systems continues. A novel development in the treatment for HCC is the drug-eluting bead (DEB), a polyvinyl alcohol-based microsphere loaded with a chemotherapeutic agent, usually doxorubicin. These microspheres are available in diameters ranging from 40 to $1,200 \mu \mathrm{m}$. The $\mathrm{DEB}$ is delivered intraarterially in a manner similar to that of conventional TACE and acts as both an occluding agent as well as a drug-loaded carrier (Fig. 4). Local ischemia and toxic death of the tumor are achieved with one device, enabling standardization. DEBs have favorable kinetics achieving higher tumor concentrations with lower plasma levels of the chemotherapic agent compared to conventional TACE [129, 130]. In DEBs, drug elution is dependent on ion exchange with the surrounding environment. This results in a controlled and sustained gradual release of the drug - unlike the more rapid separation of the drug from lipiodol-prolonging the exposure of tumor cells [131]. 
Table 2 Survival data from randomized controlled trials investigating TACE in $\mathrm{HCC}$ patients
$\mathrm{TACE}=$ transcatheter arterial chemoembolization, TAE $=$ transcatheter arterial (bland) embolization, $\mathrm{NR}=$ not reported

\begin{tabular}{|c|c|c|c|c|c|}
\hline Study & $\begin{array}{l}\text { Patients } \\
\text { (n) }\end{array}$ & Therapy & $\begin{array}{l}\text { 1-year } \\
\text { overall } \\
\text { survival (\%) }\end{array}$ & $\begin{array}{l}\text { 2-year } \\
\text { overall } \\
\text { survival (\%) }\end{array}$ & $\begin{array}{l}\text { 3-year } \\
\text { overall } \\
\text { survival (\%) }\end{array}$ \\
\hline \multirow[t]{3}{*}{ Lin et al. (1988)[119] } & \multirow[t]{3}{*}{63} & $21 \mathrm{TAE}$ & 42 & 25 & NR \\
\hline & & $21 \mathrm{TAE}+5-\mathrm{FU}$ iv & 20 & 20 & NR \\
\hline & & 215 -FU iv & 13 & 13 & NR \\
\hline \multirow[t]{2}{*}{ Pelletier et al. (1990)[120] } & \multirow[t]{2}{*}{42} & $21 \mathrm{TACE}$ & 24 & NR & NR \\
\hline & & 21 Conservative & 31 & NR & NR \\
\hline \multirow[t]{2}{*}{ Groupe d'Etude (1995)[121] } & \multirow[t]{2}{*}{96} & $50 \mathrm{TACE}$ & 62 & 38 & NR \\
\hline & & 46 Conservative & 43 & 26 & NR \\
\hline \multirow[t]{2}{*}{ Pelletier et al. (1998)[122] } & \multirow[t]{2}{*}{73} & 37 TACE & 51 & 24 & NR \\
\hline & & 36 Tamoxifen & 55 & 26 & NR \\
\hline \multirow[t]{2}{*}{ Lo et al. (2002)[117] } & \multirow[t]{2}{*}{79} & 40 TACE & 57 & 31 & 26 \\
\hline & & 39 Conservative & 32 & 11 & 3 \\
\hline \multirow[t]{3}{*}{ Llovet et al. (2002)[116] } & \multirow[t]{3}{*}{112} & 40 TACE & 82 & 63 & 29 \\
\hline & & 37 TAE & 75 & 50 & 29 \\
\hline & & 35 Conservative & 63 & 27 & 17 \\
\hline
\end{tabular}

Recently performed clinical trials reported the efficacy of DEBs in the treatment of intermediate stage HCC [130, 132-135], with good objective response (complete plus partial response) rates ranging $60 \%-85.5 \%$ (according to the EASL response criteria). The complication rates in these clinical trials ranged between 3 and $11.4 \%$, and postembolisation syndrome was observed in various severities in $18 \%$ [135], 37\% [130] and 100\% [133, 134]. Most important, there are no reports of systemic toxicity, despite the high doses of doxorubicin loaded on the DEBs.
Information on survival rates is still limited up to today, but midterm survival rates seem promising with 2-year survival up to $91 \%$ [134]. RCTs comparing conventional TACE to TACE-DEB are currently underway.

Yttrium-90 radioembolization

The use of traditional external beam radiation for the treatment of HCC has been limited because of the inability to deliver an effective dose without damaging the adjacent hepatic paren-

Table 3 Tumor response and median survival after ${ }^{90} \mathrm{Y}-\mathrm{RE}$ in $\mathrm{HCC}$ patients

\begin{tabular}{|c|c|c|c|c|c|c|c|}
\hline \multirow[t]{2}{*}{ Study } & \multirow[t]{2}{*}{ Patients (n) } & \multicolumn{4}{|c|}{ Tumor response on $\mathrm{CT}^{\mathrm{a}}$} & \multirow[t]{2}{*}{ Median survival (months) } & \multirow[t]{2}{*}{ Microspheres } \\
\hline & & CR $(\%)$ & PR $(\%)$ & $\mathrm{SD}(\%)$ & $\mathrm{PD}(\%)$ & & \\
\hline Lau et al. (1998)[142] & 71 & 0 & 27 & 65 & 8 & 9.4 & Resin \\
\hline Dancey et al. (2000) [143] & $\begin{array}{l}20 \text { (19 evaluated for } \\
\text { response) }\end{array}$ & 5 & 16 & 58 & 21 & 12.5 & Glass \\
\hline Carr et al. (2004)[144] & 65 & NR & 38 & NR & NR & Okuda I: 21.3, Okuda II: 9.9 & Glass \\
\hline Geschwind et al. (2004)[145] & 80 & NR & NR & NR & NR & Okuda I: 20.6, Okuda II: 12.6 & Glass \\
\hline Goin (2005)[146] & 121 & NR & NR & NR & NR & Low risk: 15.3 , high risk: 3.5 & Glass \\
\hline Salem (2005)[147] & 43 & NR & $47\left(79^{b}\right)$ & NR & NR & Okuda I: 24.4, Okuda II: 12.5 & Glass \\
\hline Sangro (2006)[148] & $\begin{array}{l}24 \text { ( } 21 \text { evaluated for } \\
\text { response) }\end{array}$ & NR & $88^{\mathrm{c}}(\mathrm{PR}+\mathrm{S}$ & & NR & 7 & Resin \\
\hline Young (2007)[149] & 41 & NR & NR & NR & NR & Okuda I: 21.7, Okuda II: 14.2 & Glass \\
\hline Kulik (2008)[150] & 108 & NR & $42.2\left(70^{\mathrm{b}}\right)$ & 34.7 & 23.1 & $\begin{array}{l}\text { No PVT: } 15.4 \text {, branch PVT: } 10.0 \text {, } \\
\text { main PVT: } 4.4\end{array}$ & Glass \\
\hline
\end{tabular}

Data of studies including $\geq 20$ patients

$\mathrm{CR}=$ complete response, $\mathrm{PR}=$ partial response, $\mathrm{SD}=$ stable disease, $\mathrm{PD}=$ progressive disease

$\mathrm{PVT}=$ portal vein thrombosis, $\mathrm{NR}=$ not reported

${ }^{\mathrm{a}} \mathrm{WHO}$ criteria unless otherwise explained

${ }^{\mathrm{b}}$ EASL modified WHO criteria[151]

${ }^{\mathrm{c}}$ RECIST criteria[152] 
chyma, resulting in radiation-induced liver disease (RILD), previously called radiation-induced hepatitis [136-138]. Radioembolization (RE) implements intra-arterial administration of microspheres coated with yttrium- $90\left({ }^{90} \mathrm{Y}\right)$, a Bemitting isotope, delivering selective internal radiation to the tumor. Exposure to surrounding healthy tissue is limited, avoiding injury to the normal liver parenchyma [139]. This technique was first described in 1965[140], and in recent years clinical investigation has intensified. The procedure is compromised by two components: embolization, with a micro-or macro-embolic effect, depending on the size of the microsphere, and brachytherapy $[139,141]$ (Figs. 5, 6). Two types of Y90 microspheres are in clinical use at present: glass microspheres (TheraSphere ${ }^{\circledR}$, MDS Nordion Inc., Kanata, Canada) and resin-based microspheres (SIRSpheres $^{\circledR}$, SIRTeX Medical Ltd., Sydney, Australia).

The safety and efficacy of ${ }^{90} \mathrm{Y}$-RE treatment for unresectable $\mathrm{HCC}$ has been documented, although there are no long-term survival data from randomized controlled trials to date. Table 3 summarizes the experience published on $\mathrm{HCC}$ treatment with ${ }^{90} \mathrm{Y}$-RE.

${ }^{90} \mathrm{Y}$-RE has a low toxicity profile and can be performed on an outpatient basis, with low incidence of a mild postembolization syndrome $[147,153]$. Due to the minimally embolic effect of ${ }^{90} \mathrm{Y}-\mathrm{RE}$ glass microspheres, this offers a safe treatment with favorable tumor response rates for patients with portal vein thrombosis [150].

Absolute contraindications for ${ }^{90} \mathrm{Y}-\mathrm{RE}$ treatment are significant hepatopulmonary shunting or flow to the gastrointestinal tract that cannot be corrected by catheter manipulation, demonstrated by a pre-treatment ${ }^{99 \mathrm{~m}} \mathrm{Tc}$ macro-aggregated albumin (MAA) examination [154]. Inadvertent deposition of ${ }^{90} \mathrm{Y}$ microspheres to the lungs or gastrointestinal tract can result in serious complications like radiation pneumonitis, cholecystitis, gastric ulceration, or pancreatitis pneumonitis[154-157]. The antitumor effect of ${ }^{90} \mathrm{Y}-\mathrm{RE}$ allows for the downstaging of unresectable HCC to potentially curative treatments, like surgical resection, percutaneous ablation, and bridging to liver transplantation[158-160]. Although several studies have provided useful data, there is a need for further investigation of this therapy and randomized trials comparing the efficacy of ${ }^{90}$ Y-RE to other minimally invasive locoregional therapies.

\section{Conclusion}

HCC is a heterogeneous cancer with an increasing incidence and poor prognosis. Curative therapy is only applicable to patients diagnosed at early stages of disease, emphasizing the importance of screening programs for at-risk patients. Minimally invasive image-guided ablation techniques and intra-arterial interventions offer promising potential for patients with HCC not suitable for surgical resection or transplantation.

According to the BCLC criteria, RFA is currently considered the treatment of choice for patients with unresectable small HCCs (early stage, stage A). TACE is the treatment of choice for the management of multinodular HCC (intermediate stage, stage B), preferably in asymptomatic patients with well-preserved liver function (ChildPugh class A). Sorafenib, an oral multitargeted tyrosine kinase inhibitor, has become the standard of care in advanced stage patients (stage $C$ ) with vascular involvement, extrahepatic spread or physical impairment (ChildPugh A, ECOG performance status test score 1-2). Targeted molecular therapies like Sorafenib represent the beginning of a new era in the treatment of HCC. Finally, patients at a terminal stage (stage $\mathrm{D}$ ) who have very impaired physical status (performance status test score $>2$ ) or tumor burden (stage D) should receive symptomatic treatment.

For most tumor ablative techniques, increasing tumor diameter decreases the likelihood of complete ablation. The combination of local ablation and intra-arterial therapies may help overcome shortcomings of monotherapy treatment for larger tumors, and diverse studies have shown promising potential.

A randomized controlled study showed that concomitant RFA-PEI facilitated better local tumor control and longterm survival compared to RFA alone, with 5-year overall survival rates of $49.3 \%$ versus $35.9 \%$ [161]. A metaanalysis of four randomized controlled trials [162-165] that investigated the combination of TACE or TAE plus percutaneous ablation (PEI or RFA) for the treatment of HCC showed a significant decrease in mortality favoring combination treatment compared to monotherapy (TAE, TACE, or percutaneous ablation only)[166]. In addition, there is high interest in combining local therapies with targeted molecular therapies like Sorafenib.

With ongoing research, existing image-guided local therapies will be further optimized, and promising new therapies will emerge. Combination of treatments, new technologies in imaging, and targeted drug delivery will ultimately improve the quality of life and survival of patients with HCC.

Open Access This article is distributed under the terms of the Creative Commons Attribution Noncommercial License which permits any noncommercial use, distribution, and reproduction in any medium, provided the original author(s) and source are credited.

\section{References}

1. Parkin DM, Bray F, Ferlay J, Pisani P (2005) Global cancer statistics, 2002. CA Cancer J Clin 55:74-108 
2. [No authors listed] (1987) Hepatocellular cancer: differences between high and low incidence regions. Lancet 2:1183-1184

3. El-Serag HB, Davila JA, Petersen NJ, McGlynn KA (2003) The continuing increase in the incidence of hepatocellular carcinoma in the United States: an update. Ann Intern Med 139:817-823

4. Taylor-Robinson SD, Foster GR, Arora S, Hargreaves S, Thomas HC (1997) Increase in primary liver cancer in the UK, 1979-94. Lancet 350:1142-1143

5. Beasley RP, Hwang LY, Lin CC, Chien CS (1981) Hepatocellular carcinoma and hepatitis B virus. A prospective study of 22,707 men in Taiwan. Lancet 2:1129-1133

6. Beasley RP (1988) Hepatitis B virus. The major etiology of hepatocellular carcinoma Cancer 61:1942-1956

7. Chen HL, Chang MH, Ni YH, Hsu HY, Lee PI, Lee CY et al (1996) Seroepidemiology of hepatitis B virus infection in children: Ten years of mass vaccination in Taiwan. JAMA 276:906-908

8. Chang MH, Chen CJ, Lai MS, Hsu HM, Wu TC, Kong MS et al (1997) Universal hepatitis B vaccination in Taiwan and the incidence of hepatocellular carcinoma in children. Taiwan Childhood Hepatoma Study Group. N Engl J Med 336:18551859

9. Adami HO, Hsing AW, McLaughlin JK, Trichopoulos D, Hacker D, Ekbom A et al (1992) Alcoholism and liver cirrhosis in the etiology of primary liver cancer. Int J Cancer 51:898-902

10. Bruix J, Barrera JM, Calvet X, Ercilla G, Costa J, SanchezTapias JM et al (1989) Prevalence of antibodies to hepatitis C virus in Spanish patients with hepatocellular carcinoma and hepatic cirrhosis. Lancet 2:1004-1006

11. Colombo M, Kuo G, Choo QL, Donato MF, Del NE, Tommasini MA et al (1989) Prevalence of antibodies to hepatitis $C$ virus in Italian patients with hepatocellular carcinoma. Lancet 2:10061008

12. Tsukuma H, Hiyama T, Tanaka S, Nakao M, Yabuuchi T, Kitamura T et al (1993) Risk factors for hepatocellular carcinoma among patients with chronic liver disease. N Engl J Med 328:1797-1801

13. Pons F, Varela M, Llovet JM (2005) Staging systems in hepatocellular carcinoma. HPB (Oxford) 7:35-41

14. Llovet JM, Fuster J, Bruix J (2004) The Barcelona approach: diagnosis, staging, and treatment of hepatocellular carcinoma. Liver Transpl 10:S115-S120

15. Bruix J, Llovet JM (2009) Major achievements in hepatocellular carcinoma. Lancet 373:614-616

16. Geschwind JF (2002) Chemoembolization for hepatocellular carcinoma: where does the truth lie? J Vasc Interv Radiol 13:991-994

17. Bruix J, Llovet JM (2002) Prognostic prediction and treatment strategy in hepatocellular carcinoma. Hepatology 35:519-524

18. Bruix J, Castells A, Bosch J, Feu F, Fuster J, Garcia-Pagan JC et al (1996) Surgical resection of hepatocellular carcinoma in cirrhotic patients: prognostic value of preoperative portal pressure. Gastroenterology 111:1018-1022

19. Llovet JM, Fuster J, Bruix J (1999) Intention-to-treat analysis of surgical treatment for early hepatocellular carcinoma: resection versus transplantation. Hepatology 30:1434-1440

20. Thomas MB, O'Beirne JP, Furuse J, Chan AT, bou-Alfa G, Johnson P (2008) Systemic therapy for hepatocellular carcinoma: cytotoxic chemotherapy, targeted therapy and immunotherapy. Ann Surg Oncol 15:1008-1014

21. Llovet JM, Ricci S, Mazzaferro V, Hilgard P, Gane E, Blanc JF et al (2008) Sorafenib in advanced hepatocellular carcinoma. N Engl J Med 359:378-390

22. Trinchet JC, Ganne-Carrie N, Beaugrand M (2003) Review article: intra-arterial treatments in patients with hepatocellular carcinoma. Aliment Pharmacol Ther 17(Suppl 2):111-118
23. Lu DS, Yu NC, Raman SS, Lassman C, Tong MJ, Britten C et al (2005) Percutaneous radiofrequency ablation of hepatocellular carcinoma as a bridge to liver transplantation. Hepatology 41:1130-1137

24. Mazzaferro V, Battiston C, Perrone S, Pulvirenti A, Regalia E, Romito R et al (2004) Radiofrequency ablation of small hepatocellular carcinoma in cirrhotic patients awaiting liver transplantation: a prospective study. Ann Surg 240:900-909

25. Graziadei IW, Sandmueller H, Waldenberger P, Koenigsrainer A, Nachbaur K, Jaschke W et al (2003) Chemoembolization followed by liver transplantation for hepatocellular carcinoma impedes tumor progression while on the waiting list and leads to excellent outcome. Liver Transpl 9:557-563

26. Yao FY, Kerlan RK, Hirose R, Davern TJ, Bass NM, Feng S et al (2008) Excellent outcome following down-staging of hepatocellular carcinoma prior to liver transplantation: an intention-to-treat analysis. Hepatology 48:819-827

27. Chapman WC, Majella Doyle MB, Stuart JE, Vachharajani N, Crippin JS, Anderson CD et al (2008) Outcomes of neoadjuvant transarterial chemoembolization to downstage hepatocellular carcinoma before liver transplantation. Ann Surg 248:617-625

28. Cha CH, Lee FT Jr, Gurney JM, Markhardt BK, Warner TF, Kelcz F et al (2000) CT versus sonography for monitoring radiofrequency ablation in a porcine liver. AJR Am J Roentgenol 175:705-711

29. Wood BJ, Locklin JK, Viswanathan A, Kruecker J, Haemmerich $\mathrm{D}$, Cebral J et al (2007) Technologies for guidance of radiofrequency ablation in the multimodality interventional suite of the future. J Vasc Interv Radiol 18:9-24

30. Hokland SL, Pedersen M, Salomir R, Quesson B, StodkildeJorgensen H, Moonen CT (2006) MRI-guided focused ultrasound: methodology and applications. IEEE Trans Med Imaging 25:723-731

31. Cline HE, Hynynen K, Watkins RD, Adams WJ, Schenck JF, Ettinger RH et al (1995) Focused US system for MR imagingguided tumor ablation. Radiology 194:731-737

32. Hynynen K, Freund WR, Cline HE, Chung AH, Watkins RD, Vetro JP et al (1996) A clinical, noninvasive, MR imagingmonitored ultrasound surgery method. Radiographics 16:185195

33. Kopelman D, Inbar Y, Hanannel A, Dank G, Freundlich D, Perel A et al (2006) Magnetic resonance-guided focused ultrasound surgery (MRgFUS). Four ablation treatments of a single canine hepatocellular adenoma HPB (Oxford) 8:292-298

34. Kopelman D, Inbar Y, Hanannel A, Freundlich D, Castel D, Perel A et al (2006) Magnetic resonance-guided focused ultrasound surgery (MRgFUS): ablation of liver tissue in a porcine model. Eur J Radiol 59:157-162

35. Gedroyc WM (2005) Magnetic resonance guidance of thermal ablation. Top Magn Reson Imaging 16:339-353

36. Livraghi T, Festi D, Monti F, Salmi A, Vettori C (1986) USguided percutaneous alcohol injection of small hepatic and abdominal tumors. Radiology 161:309-312

37. Shiina S, Yasuda H, Muto H, Tagawa K, Unuma T, Ibukuro K et al (1987) Percutaneous ethanol injection in the treatment of liver neoplasms. AJR Am J Roentgenol 149:949-952

38. Lencioni R, Cioni D, Crocetti L, Bartolozzi C (2004) Percutaneous ablation of hepatocellular carcinoma: state-of-the-art. Liver Transpl 10:S91-S97

39. Shiina S, Teratani T, Obi S, Sato S, Tateishi R, Fujishima T et al (2005) A randomized controlled trial of radiofrequency ablation with ethanol injection for small hepatocellular carcinoma. Gastroenterology 129:122-130

40. Lencioni R, Bartolozzi C, Caramella D, Paolicchi A, Carrai M, Maltinti $G$ et al (1995) Treatment of small hepatocellular carcinoma with percutaneous ethanol injection. Analysis of 
prognostic factors in 105 Western patients. Cancer 76:17371746

41. Livraghi T, Giorgio A, Marin G, Salmi A, De Sio I, Bolondi L et al (1995) Hepatocellular carcinoma and cirrhosis in 746 patients: long-term results of percutaneous ethanol injection. Radiology 197:101-108

42. Di SM, Buscarini L, Livraghi T, Giorgio A, Salmi A, De Sio I et al (1997) Percutaneous ethanol injection in the treatment of hepatocellular carcinoma. A multicenter survey of evaluation practices and complication rates Scand J Gastroenterol 32:11681173

43. Lencioni RA, Allgaier HP, Cioni D, Olschewski M, Deibert P, Crocetti L et al (2003) Small hepatocellular carcinoma in cirrhosis: randomized comparison of radio-frequency thermal ablation versus percutaneous ethanol injection. Radiology 228:235-240

44. Lin SM, Lin CJ, Lin CC, Hsu CW, Chen YC (2004) Radiofrequency ablation improves prognosis compared with ethanol injection for hepatocellular carcinoma $\leq 4 \mathrm{~cm}$. Gastroenterology 127:1714-1723

45. Lin SM, Lin CJ, Lin CC, Hsu CW, Chen YC (2005) Randomised controlled trial comparing percutaneous radiofrequency thermal ablation, percutaneous ethanol injection, and percutaneous acetic acid injection to treat hepatocellular carcinoma of $3 \mathrm{~cm}$ or less. Gut 54:1151-1156

46. Brunello F, Veltri A, Carucci P, Pagano E, Ciccone G, Moretto P et al (2008) Radiofrequency ablation versus ethanol injection for early hepatocellular carcinoma: A randomized controlled trial. Scand J Gastroenterol 43:727-735

47. Orlando A, Leandro G, Olivo M, Andriulli A, Cottone M (2009) Radiofrequency thermal ablation vs. percutaneous ethanol injection for small hepatocellular carcinoma in cirrhosis: meta-analysis of randomized controlled trials. Am J Gastroenterol 104:514-524

48. Curley SA, Izzo F, Delrio P, Ellis LM, Granchi J, Vallone P et al (1999) Radiofrequency ablation of unresectable primary and metastatic hepatic malignancies: results in 123 patients. Ann Surg 230:1-8

49. Curley SA, Izzo F, Ellis LM, Nicolas VJ, Vallone P (2000) Radiofrequency ablation of hepatocellular cancer in 110 patients with cirrhosis. Ann Surg 232:381-391

50. Goldberg SN, Gazelle GS, Solbiati L, Livraghi T, Tanabe KK, Hahn PF et al (1998) Ablation of liver tumors using percutaneous RF therapy. AJR Am J Roentgenol 170:1023-1028

51. Livraghi T, Goldberg SN, Lazzaroni S, Meloni F, Ierace T, Solbiati L et al (2000) Hepatocellular carcinoma: radiofrequency ablation of medium and large lesions. Radiology 214:761-768

52. Livraghi T, Goldberg SN, Lazzaroni S, Meloni F, Solbiati L, Gazelle GS (1999) Small hepatocellular carcinoma: treatment with radio-frequency ablation versus ethanol injection. Radiology 210:655-661

53. Buscarini L, Buscarini E, Di SM, Vallisa D, Quaretti P, Rocca A (2001) Percutaneous radiofrequency ablation of small hepatocellular carcinoma: long-term results. Eur Radiol 11:914-921

54. Lencioni R, Cioni D, Crocetti L, Franchini C, Pina CD, Lera J et al (2005) Early-stage hepatocellular carcinoma in patients with cirrhosis: long-term results of percutaneous image-guided radiofrequency ablation. Radiology 234:961-967

55. Tateishi R, Shiina S, Teratani T, Obi S, Sato S, Koike Y et al (2005) Percutaneous radiofrequency ablation for hepatocellular carcinoma. An analysis of 1,000 cases. Cancer 103:1201-1209

56. Raut CP, Izzo F, Marra P, Ellis LM, Vauthey JN, Cremona F et al (2005) Significant long-term survival after radiofrequency ablation of unresectable hepatocellular carcinoma in patients with cirrhosis. Ann Surg Oncol 12:616-628

57. Machi J, Bueno RS, Wong LL (2005) Long-term follow-up outcome of patients undergoing radiofrequency ablation for unresectable hepatocellular carcinoma. World J Surg 29:1364-1373

58. Cabassa P, Donato F, Simeone F, Grazioli L, Romanini L (2006) Radiofrequency ablation of hepatocellular carcinoma: long-term experience with expandable needle electrodes. AJR Am J Roentgenol 186:S316-S321

59. Choi D, Lim HK, Rhim H, Kim YS, Lee WJ, Paik SW et al (2007) Percutaneous radiofrequency ablation for early-stage hepatocellular carcinoma as a first-line treatment: long-term results and prognostic factors in a large single-institution series. Eur Radiol 17:684-692

60. Yan K, Chen MH, Yang W, Wang YB, Gao W, Hao CY et al (2008) Radiofrequency ablation of hepatocellular carcinoma: long-term outcome and prognostic factors. Eur J Radiol 67:336347

61. Ueno S, Sakoda M, Kubo F, Hiwatashi K, Tateno T, Baba Y et al (2009) Surgical resection versus radiofrequency ablation for small hepatocellular carcinomas within the Milan criteria. J Hepatobiliary Pancreat Surg 16:359-366

62. Wiersinga WJ, Jansen MC, Straatsburg IH, Davids PH, Klaase JM, Gouma DJ et al (2003) Lesion progression with time and the effect of vascular occlusion following radiofrequency ablation of the liver. Br J Surg 90:306-312

63. Goldberg SN, Hahn PF, Tanabe KK, Mueller PR, Schima W, Athanasoulis CA et al (1998) Percutaneous radiofrequency tissue ablation: does perfusion-mediated tissue cooling limit coagulation necrosis? J Vasc Interv Radiol 9:101-111

64. Patterson EJ, Scudamore CH, Owen DA, Nagy AG, Buczkowski AK (1998) Radiofrequency ablation of porcine liver in vivo: effects of blood flow and treatment time on lesion size. Ann Surg 227:559-565

65. Miao Y, Ni Y, Mulier S, Wang K, Hoey MF, Mulier P et al (1997) Ex vivo experiment on radiofrequency liver ablation with saline infusion through a screw-tip cannulated electrode. J Surg Res 71:19-24

66. Goldberg SN, Gazelle GS, Dawson SL, Rittman WJ, Mueller PR, Rosenthal DI (1995) Tissue ablation with radiofrequency using multiprobe arrays. Acad Radiol 2:670-674

67. Veenendaal LM, Borel Rinkes IH, Van Hillegersberg R (2006) Multipolar radiofrequency ablation of large hepatic metastases of endocrine tumours. Eur J Gastroenterol Hepatol 18:89-92

68. Rhim H (2005) Complications of radiofrequency ablation in hepatocellular carcinoma. Abdom Imaging 30:409-418

69. Llovet JM, Vilana R, Bru C, Bianchi L, Salmeron JM, Boix L et al (2001) Increased risk of tumor seeding after percutaneous radiofrequency ablation for single hepatocellular carcinoma. Hepatology 33:1124-1129

70. Jaskolka JD, Asch MR, Kachura JR, Ho CS, Ossip M, Wong F et al (2005) Needle tract seeding after radiofrequency ablation of hepatic tumors. J Vasc Interv Radiol 16:485-491

71. Livraghi T, Lazzaroni S, Meloni F, Solbiati L (2005) Risk of tumour seeding after percutaneous radiofrequency ablation for hepatocellular carcinoma. Br J Surg 92:856-858

72. Imamura J, Tateishi R, Shiina S, Goto E, Sato T, Ohki $\mathrm{T}$ et al (2008) Neoplastic seeding after radiofrequency ablation for hepatocellular carcinoma. Am J Gastroenterol 103:3057-3062

73. Snoeren N, Jansen MC, Rijken AM, van Hillegersberg R, Slooter G, Klaase J et al (2009) Assessment of viable tumour tissue attached to needle applicators after local ablation of liver tumours. Dig Surg 26:56-62

74. Livraghi T (2009) Single HCC smaller than $2 \mathrm{~cm}$ : surgery or ablation: Interventional oncologist's perspective. J Hepatobiliary Pancreat Surg 
75. Takayama T, Makuuchi M, Hasegawa K (2009) Single HCC smaller than $2 \mathrm{~cm}$ : surgery or ablation?: Surgeon's perspective. J Hepatobiliary Pancreat Surg

76. Chen MS, Li JQ, Zheng Y, Guo RP, Liang HH, Zhang YQ et al (2006) A prospective randomized trial comparing percutaneous local ablative therapy and partial hepatectomy for small hepatocellular carcinoma. Ann Surg 243:321-328

77. Rubinsky B, Lee CY, Bastacky J, Onik G (1990) The process of freezing and the mechanism of damage during hepatic cryosurgery. Cryobiology 27:85-97

78. Hinshaw JL, Lee FT Jr (2007) Cryoablation for liver cancer. Tech Vasc Interv Radiol 10:47-57

79. Haddad FF, Chapman WC, Wright JK, Blair TK, Pinson CW (1998) Clinical experience with cryosurgery for advanced hepatobiliary tumors. J Surg Res 75:103-108

80. Zhou XD, Tang ZY (1998) Cryotherapy for primary liver cancer. Semin Surg Oncol 14:171-174

81. Pearson AS, Izzo F, Fleming RY, Ellis LM, Delrio P, Roh MS et al (1999) Intraoperative radiofrequency ablation or cryoablation for hepatic malignancies. Am J Surg 178:592-599

82. Seifert JK, Morris DL (1999) World survey on the complications of hepatic and prostate cryotherapy. World J Surg 23:109-113

83. Dong BW, Liang P, Yu XL, Zeng XQ, Wang PJ, Su L et al (1998) Sonographically guided microwave coagulation treatment of liver cancer: an experimental and clinical study. AJR Am J Roentgenol 171:449-454

84. Lu MD, Chen JW, Xie XY, Liu L, Huang XQ, Liang LJ et al (2001) Hepatocellular carcinoma: US-guided percutaneous microwave coagulation therapy. Radiology 221:167-172

85. Dong B, Liang P, Yu X, Su L, Yu D, Cheng Z et al (2003) Percutaneous sonographically guided microwave coagulation therapy for hepatocellular carcinoma: results in 234 patients. AJR Am J Roentgenol 180:1547-1555

86. Liang P, Dong B, Yu X, Yu D, Wang Y, Feng L et al (2005) Prognostic factors for survival in patients with hepatocellular carcinoma after percutaneous microwave ablation. Radiology 235:299-307

87. Seki T, Wakabayashi M, Nakagawa T, Imamura M, Tamai T, Nishimura A et al (1999) Percutaneous microwave coagulation therapy for patients with small hepatocellular carcinoma: comparison with percutaneous ethanol injection therapy. Cancer 85:1694-1702

88. Ohmoto K, Yoshioka N, Tomiyama Y, Shibata N, Kawase T, Yoshida K et al (2006) Thermal ablation therapy for hepatocellular carcinoma: comparison between radiofrequency ablation and percutaneous microwave coagulation therapy. Hepatogastroenterology 53:651-654

89. Ohmoto K, Yoshioka N, Tomiyama Y, Shibata N, Kawase T, Yoshida K et al (2007) Radiofrequency ablation versus percutaneous microwave coagulation therapy for small hepatocellular carcinomas: a retrospective comparative study. Hepatogastroenterology 54:985-989

90. Ohmoto K, Yoshioka N, Tomiyama Y, Shibata N, Kawase T, Yoshida K et al (2009) Comparison of therapeutic effects between radiofrequency ablation and percutaneous microwave coagulation therapy for small hepatocellular carcinomas. J Gastroenterol Hepatol 24:223-227

91. Lu MD, Xu HX, Xie XY, Yin XY, Chen JW, Kuang M et al (2005) Percutaneous microwave and radiofrequency ablation for hepatocellular carcinoma: a retrospective comparative study. J Gastroenterol 40:1054-1060

92. Shibata T, Iimuro Y, Yamamoto Y, Maetani Y, Ametani F, Itoh K et al (2002) Small hepatocellular carcinoma: comparison of radiofrequency ablation and percutaneous microwave coagulation therapy. Radiology 223:331-337
93. Vogl TJ, Eichler K, Straub R, Engelmann K, Zangos S, Woitaschek D et al (2001) Laser-induced thermotherapy of malignant liver tumors: general principals, equipment(s), procedure(s)-side effects, complications and results. Eur J Ultrasound 13:117-127

94. Germer CT, Roggan A, Ritz JP, Isbert C, Albrecht D, Muller G et al (1998) Optical properties of native and coagulated human liver tissue and liver metastases in the near infrared range. Lasers Surg Med 23:194-203

95. Gough-Palmer AL, Gedroyc WM (2008) Laser ablation of hepatocellular carcinoma-a review. World J Gastroenterol 14:7170-7174

96. Pacella CM, Bizzarri G, Magnolfi F, Cecconi P, Caspani B, Anelli V et al (2001) Laser thermal ablation in the treatment of small hepatocellular carcinoma: results in 74 patients. Radiology 221:712-720

97. Pacella CM, Bizzarri G, Francica G, Bianchini A, De NS, Pacella $S$ et al (2005) Percutaneous laser ablation in the treatment of hepatocellular carcinoma with small tumors: analysis of factors affecting the achievement of tumor necrosis. J Vasc Interv Radiol 16:1447-1457

98. Pacella CM, Bizzarri G, Francica G, Forlini G, Petrolati A, Valle D et al (2006) Analysis of factors predicting survival in patients with hepatocellular carcinoma treated with percutaneous laser ablation. J Hepatol 44:902-909

99. Pacella CM, Francica G, Di Lascio FM, Arienti V, Antico E, Caspani B et al (2009) Long-term outcome of cirrhotic patients with early hepatocellular carcinoma treated with ultrasoundguided percutaneous laser ablation: a retrospective analysis. J Clin Oncol 27:2615-2621

100. Dick EA, Joarder R, de JM T-R, SD THC, Foster GR et al (2003) MR-guided laser thermal ablation of primary and secondary liver tumours. Clin Radiol 58:112-120

101. Eichler K, Mack MG, Straub R, Engelmann K, Zangos S, Woitaschek D et al (2001) Oligonodular hepatocellular carcinoma (HCC): MR-controlled laser-induced thermotherapy. Radiologe 41:915-922

102. Arienti V, Pretolani S, Pacella CM, Magnolfi F, Caspani B, Francica $\mathrm{G}$ et al (2008) Complications of laser ablation for hepatocellular carcinoma: a multicenter study. Radiology 246:947-955

103. Pompili M, Pacella CM, Francica G, Angelico M, Tisone G, Craboledda P et al (2009) Percutaneous laser ablation of hepatocellular carcinoma in patients with liver cirrhosis awaiting liver transplantation. Eur J Radiol

104. Ferrari FS, Megliola A, Scorzelli A, Stella A, Vigni F, Drudi FM et al (2007) Treatment of small HCC through radiofrequency ablation and laser ablation. Comparison of techniques and longterm results. Radiol Med 112:377-393

105. Chen L, Rivens I, ter Haar G, Riddler S, Hill CR, Bensted JP (1993) Histological changes in rat liver tumours treated with high-intensity focused ultrasound. Ultrasound Med Biol 19:67-74

106. Wu F, Wang ZB, Chen WZ, Zhu H, Bai J, Zou JZ et al (2004) Extracorporeal high intensity focused ultrasound ablation in the treatment of patients with large hepatocellular carcinoma. Ann Surg Oncol 11:1061-1069

107. Zhu H, Zhou K, Zhang L, Jin C, Peng S, Yang W et al (2008) High intensity focused ultrasound (HIFU) therapy for local treatment of hepatocellular carcinoma: Role of partial rib resection. Eur J Radiol

108. Civale J, Clarke R, Rivens I, ter Haar G (2006) The use of a segmented transducer for rib sparing in HIFU treatments. Ultrasound Med Biol 32:1753-1761

109. Liu HL, Chang H, Chen WS, Shih TC, Hsiao JK, Lin WL (2007) Feasibility of transrib focused ultrasound thermal ablation for liver tumors using a spherically curved 2D array: a numerical study. Med Phys 34:3436-3448 
110. Breedis C, Young G (1954) The blood supply of neoplasms in the liver. Am J Pathol 30:969-977

111. Marelli L, Stigliano R, Triantos C, Senzolo M, Cholongitas E, Davies $N$ et al (2007) Transarterial therapy for hepatocellular carcinoma: which technique is more effective? A systematic review of cohort and randomized studies. Cardiovasc Intervent Radiol 30:6-25

112. Pleguezuelo M, Marelli L, Misseri M, Germani G, Calvaruso V, Xiruochakis E et al (2008) TACE versus TAE as therapy for hepatocellular carcinoma. Expert Rev Anticancer Ther 8:16231641

113. Kanematsu T, Inokuchi K, Sugimachi K, Furuta T, Sonoda T, Tamura S et al (1984) Selective effects of Lipiodolized antitumor agents. J Surg Oncol 25:218-226

114. Bhattacharya S, Novell JR, Winslet MC, Hobbs KE (1994) Iodized oil in the treatment of hepatocellular carcinoma. Br J Surg 81:1563-1571

115. Geschwind JF, Ramsey DE, Cleffken B, van der Wal BC, Kobeiter H, Juluru K et al (2003) Transcatheter arterial chemoembolization of liver tumors: effects of embolization protocol on injectable volume of chemotherapy and subsequent arterial patency. Cardiovasc Intervent Radiol 26:111-117

116. Llovet JM, Real MI, Montana X, Planas R, Coll S, Aponte J et al (2002) Arterial embolisation or chemoembolisation versus symptomatic treatment in patients with unresectable hepatocellular carcinoma: a randomised controlled trial. Lancet 359:1734-1739

117. Lo CM, Ngan H, Tso WK, Liu CL, Lam CM, Poon RT et al (2002) Randomized controlled trial of transarterial lipiodol chemoembolization for unresectable hepatocellular carcinoma. Hepatology 35:1164-1171

118. Llovet JM, Bruix J (2003) Systematic review of randomized trials for unresectable hepatocellular carcinoma: Chemoembolization improves survival. Hepatology 37:429-442

119. Lin DY, Liaw YF, Lee TY, Lai CM (1988) Hepatic arterial embolization in patients with unresectable hepatocellular carcinoma-a randomized controlled trial. Gastroenterology 94:453456

120. Pelletier G, Roche A, Ink O, Anciaux ML, Derhy S, Rougier P et al (1990) A randomized trial of hepatic arterial chemoembolization in patients with unresectable hepatocellular carcinoma. J Hepatol 11:181-184

121. Groupe d'Etude et de Traitement du Carcinome Hepatocellulaire (1995) A comparison of lipiodol chemoembolization and conservative treatment for unresectable hepatocellular carcinoma. N Engl J Med 332:1256-1261

122. Pelletier G, Ducreux M, Gay F, Luboinski M, Hagege H, Dao T et al (1998) Treatment of unresectable hepatocellular carcinoma with lipiodol chemoembolization: a multicenter randomized trial. Groupe CHC J Hepatol 29:129-134

123. Wigmore SJ, Redhead DN, Thomson BN, Currie EJ, Parks RW, Madhavan KK et al (2003) Postchemoembolisation syndrometumour necrosis or hepatocyte injury? Br J Cancer 89:1423-1427

124. Bruix J, Sala M, Llovet JM (2004) Chemoembolization for hepatocellular carcinoma. Gastroenterology 127:S179-S188

125. Buijs M, Vossen JA, Frangakis C, Hong K, Georgiades CS, Chen $\mathrm{Y}$ et al (2008) Nonresectable hepatocellular carcinoma: long-term toxicity in patients treated with transarterial chemoembolizationsingle-center experience. Radiology 249:346-354

126. Huo TI, Wu JC, Lee PC, Chang FY, Lee SD (2004) Incidence and risk factors for acute renal failure in patients with hepatocellular carcinoma undergoing transarterial chemoembolization: a prospective study. Liver Int 24:210-215

127. Mathupala SP, Rempel A, Pedersen PL (2001) Glucose catabolism in cancer cells: identification and characterization of a marked activation response of the type II hexokinase gene to hypoxic conditions. J Biol Chem 276:43407-43412
128. Lau WY, Lai EC (2008) Hepatocellular carcinoma: current management and recent advances. Hepatobiliary Pancreat Dis Int 7:237-257

129. Hong K, Khwaja A, Liapi E, Torbenson MS, Georgiades CS, Geschwind JF (2006) New intra-arterial drug delivery system for the treatment of liver cancer: preclinical assessment in a rabbit model of liver cancer. Clin Cancer Res 12:2563-2567

130. Varela M, Real MI, Burrel M, Forner A, Sala M, Brunet M et al (2007) Chemoembolization of hepatocellular carcinoma with drug eluting beads: efficacy and doxorubicin pharmacokinetics. J Hepatol 46:474-481

131. Lewis AL, Gonzalez MV, Lloyd AW, Hall B, Tang Y, Willis SL et al (2006) DC bead: in vitro characterization of a drug-delivery device for transarterial chemoembolization. J Vasc Interv Radiol $17: 335-342$

132. Poon RT, Tso WK, Pang RW, Ng KK, Woo R, Tai KS et al (2007) A phase I/II trial of chemoembolization for hepatocellular carcinoma using a novel intra-arterial drug-eluting bead. Clin Gastroenterol Hepatol 5:1100-1108

133. Malagari K, Chatzimichael K, Alexopoulou E, Kelekis A, Hall B, Dourakis S et al (2008) Transarterial chemoembolization of unresectable hepatocellular carcinoma with drug eluting beads: results of an open-label study of 62 patients. Cardiovasc Intervent Radiol 31:269-280

134. Malagari K, Alexopoulou E, Chatzimichail K, Hall B, Koskinas J, Ryan S et al (2008) Transcatheter chemoembolization in the treatment of HCC in patients not eligible for curative treatments: midterm results of doxorubicin-loaded DC bead. Abdom Imaging 33:512-519

135. Grosso M, Vignali C, Quaretti P, Nicolini A, Melchiorre F, Gallarato $G$ et al (2008) Transarterial chemoembolization for hepatocellular carcinoma with drug-eluting microspheres: preliminary results from an Italian multicentre study. Cardiovasc Intervent Radiol 31:1141-1149

136. JA Ingold, GB Reed, HS Kaplan, MA Bagshaw (1965) Radiation hepatitis. Am J Roentgenol Radium Ther Nucl Med 93:200-208

137. Lawrence TS, Robertson JM, Anscher MS, Jirtle RL, Ensminger WD, Fajardo LF (1995) Hepatic toxicity resulting from cancer treatment. Int J Radiat Oncol Biol Phys 31:1237-1248

138. Cheng JC, Wu JK, Huang CM, Huang DY, Cheng SH, Lin YM et al (2002) Radiation-induced liver disease after radiotherapy for hepatocellular carcinoma: clinical manifestation and dosimetric description. Radiother Oncol 63:41-45

139. Kennedy AS, Nutting C, Coldwell D, Gaiser J, Drachenberg C (2004) Pathologic response and microdosimetry of (90)Y microspheres in man: review of four explanted whole livers. Int $\mathrm{J}$ Radiat Oncol Biol Phys 60:1552-1563

140. Ariel IM (1965) Treatment of inoperable primary pancreatic and liver cancer by the intra-arterial administration of radioactive isotopes (Y90 radiating microspheres). Ann Surg 162:267-278

141. Sato K, Lewandowski RJ, Bui JT, Omary R, Hunter RD, Kulik L et al (2006) Treatment of unresectable primary and metastatic liver cancer with yttrium-90 microspheres (TheraSphere): assessment of hepatic arterial embolization. Cardiovasc Intervent Radiol 29:522529

142. Lau WY, Ho S, Leung TW, Chan M, Ho R, Johnson PJ et al (1998) Selective internal radiation therapy for nonresectable hepatocellular carcinoma with intraarterial infusion of $90 \mathrm{yttrium}$ microspheres. Int J Radiat Oncol Biol Phys 40:583-592

143. Dancey JE, Shepherd FA, Paul K, Sniderman KW, Houle S, Gabrys J et al (2000) Treatment of nonresectable hepatocellular carcinoma with intrahepatic 90Y-microspheres. J Nucl Med 41:1673-1681

144. Carr BI (2004) Hepatic arterial 90Yttrium glass microspheres (Therasphere) for unresectable hepatocellular carcinoma: interim 
safety and survival data on 65 patients. Liver Transpl 10:S107S110

145. Geschwind JF, Salem R, Carr BI, Soulen MC, Thurston KG, Goin KA et al (2004) Yttrium-90 microspheres for the treatment of hepatocellular carcinoma. Gastroenterology 127:S194-S205

146. Goin JE, Salem R, Carr BI, Dancey JE, Soulen MC, Geschwind JF et al (2005) Treatment of unresectable hepatocellular carcinoma with intrahepatic yttrium 90 microspheres: a riskstratification analysis. J Vasc Interv Radiol 16:195-203

147. Salem R, Lewandowski RJ, Atassi B, Gordon SC, Gates VL, Barakat $O$ et al (2005) Treatment of unresectable hepatocellular carcinoma with use of $90 \mathrm{Y}$ microspheres (TheraSphere): safety, tumor response, and survival. J Vasc Interv Radiol 16:1627-1639

148. Sangro B, Bilbao JI, Boan J, Martinez-Cuesta A, Benito A, Rodriguez $\mathrm{J}$ et al (2006) Radioembolization using 90Y-resin microspheres for patients with advanced hepatocellular carcinoma. Int J Radiat Oncol Biol Phys 66:792-800

149. Young JY, Rhee TK, Atassi B, Gates VL, Kulik L, Mulcahy MF et al (2007) Radiation dose limits and liver toxicities resulting from multiple yttrium-90 radioembolization treatments for hepatocellular carcinoma. J Vasc Interv Radiol 18:1375-1382

150. Kulik LM, Carr BI, Mulcahy MF, Lewandowski RJ, Atassi B, Ryu RK et al (2008) Safety and efficacy of 90Y radiotherapy for hepatocellular carcinoma with and without portal vein thrombosis. Hepatology 47:71-81

151. Bruix J, Sherman M, Llovet JM, Beaugrand M, Lencioni R, Burroughs AK et al (2001) Clinical management of hepatocellular carcinoma. Conclusions of the Barcelona-2000 EASL conference. European Association for the Study of the Liver. J Hepatol 35:421430

152. Therasse P, Arbuck SG, Eisenhauer EA, Wanders J, Kaplan RS, Rubinstein L et al (2000) New guidelines to evaluate the response to treatment in solid tumors. European Organization for Research and Treatment of Cancer, National Cancer Institute of the United States, National Cancer Institute of Canada. J Natl Cancer Inst 92:205-216

153. Ibrahim SM, Lewandowski RJ, Sato KT, Gates VL, Kulik L, Mulcahy MF et al (2008) Radioembolization for the treatment of unresectable hepatocellular carcinoma: a clinical review. World J Gastroenterol 14:1664-1669

154. Murthy R, Nunez R, Szklaruk J, Erwin W, Madoff DC, Gupta S et al (2005) Yttrium-90 microsphere therapy for hepatic malignancy: devices, indications, technical considerations, and potential complications. Radiographics 25(Suppl 1):S41-S55

155. Murthy R, Brown DB, Salem R, Meranze SG, Coldwell DM, Krishnan S et al (2007) Gastrointestinal complications associated with hepatic arterial Yttrium-90 microsphere therapy. J Vasc Interv Radiol 18:553-561
156. Carretero C, Munoz-Navas M, Betes M, Angos R, Subtil JC, Fernandez-Urien I et al (2007) Gastroduodenal injury after radioembolization of hepatic tumors. Am J Gastroenterol 102:1216-1220

157. Leung TW, Lau WY, Ho SK, Ward SC, Chow JH, Chan MS et al (1995) Radiation pneumonitis after selective internal radiation treatment with intraarterial 90yttrium-microspheres for inoperable hepatic tumors. Int J Radiat Oncol Biol Phys 33:919-924

158. Lau WY, Ho SK, Yu SC, Lai EC, Liew CT, Leung TW (2004) Salvage surgery following downstaging of unresectable hepatocellular carcinoma. Ann Surg 240:299-305

159. Kulik LM, Mulcahy MF, Hunter RD, Nemcek AA Jr, Abecassis MM, Salem R (2005) Use of yttrium-90 microspheres (TheraSphere) in a patient with unresectable hepatocellular carcinoma leading to liver transplantation: a case report. Liver Transpl $11: 1127-1131$

160. Kulik LM, Atassi B, van Holsbeck L, Souman T, Lewandowski RJ, Mulcahy MF et al (2006) Yttrium-90 microspheres (TheraSphere) treatment of unresectable hepatocellular carcinoma: downstaging to resection, RFA and bridge to transplantation. J Surg Oncol 94:572586

161. Zhang YJ, Liang HH, Chen MS, Guo RP, Li JQ, Zheng Y et al (2007) Hepatocellular carcinoma treated with radiofrequency ablation with or without ethanol injection: a prospective randomized trial. Radiology 244:599-607

162. Bartolozzi C, Lencioni R, Caramella D, Vignali C, Cioni R, Mazzeo S et al (1995) Treatment of large HCC: transcatheter arterial chemoembolization combined with percutaneous ethanol injection versus repeated transcatheter arterial chemoembolization. Radiology 197:812-818

163. Koda M, Murawaki Y, Mitsuda A, Oyama K, Okamoto K, Idobe Y et al (2001) Combination therapy with transcatheter arterial chemoembolization and percutaneous ethanol injection compared with percutaneous ethanol injection alone for patients with small hepatocellular carcinoma: a randomized control study. Cancer 92:1516-1524

164. Akamatsu M, Yoshida H, Obi S, Sato S, Koike Y, Fujishima T et al (2004) Evaluation of transcatheter arterial embolization prior to percutaneous tumor ablation in patients with hepatocellular carcinoma: a randomized controlled trial. Liver Int 24:625-629

165. Becker G, Soezgen T, Olschewski M, Laubenberger J, Blum HE, Allgaier HP (2005) Combined TACE and PEI for palliative treatment of unresectable hepatocellular carcinoma. World J Gastroenterol 11:6104-6109

166. Marelli L, Stigliano R, Triantos C, Senzolo M, Cholongitas E, Davies N et al (2006) Treatment outcomes for hepatocellular carcinoma using chemoembolization in combination with other therapies. Cancer Treat Rev 32:594-606 